\title{
Peranan Dinas Lingkungan Hidup Dalam Pelaksanaan Peraturan Daerah Kabupaten Dharmasraya Nomor 9 Tahun 2015 Tentang Pengelolaan Sampah Dalam Perspektif Fiqih Siyasah Dusturiyah
}

\author{
Nada Prastika Fadillah¹, Irma Suryani ${ }^{2}$ \\ ${ }^{1}$ Institut Agama Islam Negeri (IAIN) BatusangkarFakultas Syariah \\ e-mail: nadaprastikafadillah@gmail.com \\ ${ }^{2}$ Universitas Islam Negeri (UIN) Imam Bonjol Padang \\ e-mail: irmasuryani6599@yahoo.com
}

\begin{abstract}
Jurusan Hukum Tata Negara, Fakultas Syariah, Institut Agama Islam Negeri (LAIN) Batusangkar tabun akademik. 2020. Dalam penulisan skripsi ini yang menjadi fokus penelitian adalah bagaimana Peranan Dinas Lingkungan Hidup dalam pelaksanaan Peraturan Daerah Kabupaten Dharmasraya Nomor 9 Tahun 2015 Tentang Pengelolaan Sampah ditengah- tengah masyarakat tepatnya di Kecamatan Sungai Rumbai. Penelitian ini adalah penelitian lapangan (field research), yaitu penelitian yang dilakukan di Kantor Dinas Lingkungan Hidup Kabupaten Dharmasraya. Sumber data dari penelitian ini terdiri dari sumber data primer dan sumber data sekunder. Sumber data primer yaitu, Kasi Bidang Penataan Dan Pentaatan Lingkungan Hidup, Kasi Bidang Pengelolaan Sampah Dan Limbah B3, Dan Masyarakat Serta Tim Kebersiban Di Kecamatan Sungai Rumbai. Sedangkan sumber data sekunder dari penelitian ini yaitu Peraturan Daerah Kabupaten Dharmasraya Nomor 9 Tabun 2015 Tentang Pengelolaan Sampah, Peraturan Bupati Nomor 51 Tabun 2019 Tentang Kedudukan, Susunan Organisasi, Tugas, Fungsi, Uraian Tugas Jabatan Serta Tata Kerja Dinas Lingkungan Hidup Kabupaten Dharmasraya dan beberapa buku. Penelitian ini menggunakan teknik pengumpulan data dengan melakukan wawancara dan dokumentasi. Setelah data tersebut diperoleh selanjutnya data tersebut di analisa menggunakan analisa kualitatif. Untuk menjamin keabsahan data yang diperoleb penulis menggunakan metode triangulasi data. Penelitian yang penulis lakukan ditemukan babwa, Dinas Lingkungan Hidup Kabupaten Dharmasraya mempunyai peranan dalam mengatasi permasalahan lingkungan dengan melakukan pengawasan iæin mengendalikan lingkungan, penyedian sarana dan prasarana tempat pengelolaan sampah serta memberikan sosialisasi kepada pelaku kegiatan pengelolaan sampah namun pelaksanaannya masib belum optimal dilakukan oleh Dinas Lingkungan Hidup Kabupaten Dharmasraya. Dampak yang ditimbulkan dari kurang optimalnya Dinas Lingkungan Hidup dalam pelaksanaan peranannya memberikan dampak negatif yaitu bagi masyarakat yang seharusnya mendapatkan layanan tempat pengelolaan sampab jadi tidak terlayani dikarenakan kurangnya dana yang tersedia serta terbatasnya jumlah tenaga kerja membuat Dinas Lingkungan Hidup tidak bisa berkerja secara optimal. Perspektif Fiqh Siyasah Dusturiyah terhadap Peraturan Daerah Kabupaten Dharmasraya Nomor 9 Tahun 2015 Tentang Pengelolaan Sampah. Dalam Islam tidak ada larangan secara khusus mengatur tentang pengelolaan sampab, namun bukumnya akan haram jika menimbulkan bahaya yang mengancam jiwa, akal, harta, keturunan, agama, dan negara.
\end{abstract}

Kata kunci: Implementasi Peraturan Daerah, Peranan Dinas Lingkungan Hidup, Siyasah Dusturiyah

\section{PENDAHULUAN}

$S$ ampah merupakan salah satu masalah yang kompleks dihadapi oleh negara-negara berkembang maupun di negara-negara maju di dunia. Dalam Undang- Undang 
Nomor 18 Tahun 2008 Pasal 1 Tentang Pengelolaan Sampah dijelaskan bahwa "Sampah Adalah Sisa Kegiatan Sehari-Hari Manusia Dan/Atau Proses Alam Yang Berbentuk Padat". Sehingga pengelolaannya perlu dilakukan secara komprehensif dan terpadu dari hulu ke hilir agar memberikan manfaat secara ekonomi, sehat bagi masyarakat, dan aman bagi lingkungan, serta dapat mengubah perilaku masyarakat. Apabila pengelolaan sampah tidak sesuai dengan metode dan teknik pengelolaan sampah yang berwawasan lingkungan, dikhawatirkan akan mendapatkan dampak negatif seperti pencemaran lingkungan, konflik sosial, dan menimbulkan penyakit bagi masyarakat (UUD Nomor 18 Tahun 2008).

Undang-Undang Dasar Negara Republik Indonesia Tahun 1945 pada alinea ke IV dijelaskan bahwa tujuan dari Negara Indonesia adalah melindungi segenap Bangsa Indonesia dan seluruh tumpah darah Indonesia, memajukan kesejahteraan umum, mencerdaskan kehidupan bangsa dan ikut melaksanakan ketertiban dunia. Sesuai dengan pasal $28 \mathrm{H}$ ayat (1) Undang- Undang Dasar Negara Republik Indonesia Tahun 1945 menyatakan bahwa "Setiap orang berhak hidup sejahtera lahir dan batin, bertempat tinggal dan mendapatkan lingkungan hidup yang baik dan sehat serta berhak memperoleh pelayanan kesehatan" (Taufiqurrahman, 2016:1).

Amanat Undang-Undang Dasar tersebut memberikan konsekuensi bahwa pemerintah wajib memberikan pelayanan publik dalam pengelolaan sampah. Hal itu membawa konsekuensi hukum bahwa pemerintah merupakan pihak yang berwenang dan bertanggung jawab di bidang pengelolaan sampah meskipun secara operasional pengelolaannya dapat bermitra dengan badan usaha. Dalam rangka menyelenggarakan pengelolaan sampah secara terpadu dan komprehensif, pemenuhan hak dan kewajiban masyarakat, serta tugas dan wewenang Pemerintah dan pemerintahan daerah untuk melaksanakan pelayanan publik, diperlukan payung hukum dalam bentuk undangundang.

Sesuai dengan amanat Undang-Undang Dasar Negara Republik Indonesia tahun 1945, Pemerintah telah menggunakan wewenangnya dalam memberikan kepastian hukum serta kejelasan tanggung jawab dengan diundangkannya Undang-Undang Nomor. 18 Tahun 2008 tentang Pengelolaan Sampah yang tujuannya untuk mengurangi masalah sampah di Indonesia. Dan Peraturan Menteri Dalam Negeri Nomor 33 Tahun 2010 Tentang Pedoman Pengelolaan Sampah, Peraturan Pemerintah Nomor 81 Tahun 2012 tentang Pengelolaan Sampah Rumah Tangga dan Sampah Sejenis Sampah Rumah Tangga, serta Peraturan Menteri Pekerjaan Umum Nomor 03/PRT/M/2013 tentang Penyelenggaraan Prasarana dan Sarana Persampahan dalam Penanganan Sampah Rumah Tangga dan Sampah sejenis Rumah Tangga hingga beberapa peraturan lanjutan di tingkat daerah sesuai dengan kebutuhan daerah masingmasing (Diandara, 2017: 1-2).

Sebagai upaya untuk mempercepat terselenggaranya pengelolaan sampah yang baik bagi masyarakat pemerintah memberikan wewenang kepada pemerintah daerah untuk mengatur dan mungurus urusan daerahnya sendiri menururt asas ekonomi dan tugas pembantuan. Pemberian otonomi luas kepada daerah diarahkan untuk mempercepat terwujudnya kesejahteraan masyarakat melalui peningkatan pelayanan, 
pemberdayaan, dan peran serta masayarakat. Pemberian hak Otonomi Daerah ini diatur dalam Pasal 18 Ayat (5) Undang-Undang Nomor 23 Tahun 2014 tentang Pemerintahan Daerah. Dan setelah adanya amandemen Undang-Undang Nomor 23 Tahun 2014 Jo Undang-Undang Nomor 9 Tahun 2015 maka secara resmi negara memberikan hak otonomi kepada daerah untuk mengurus, mengatur, dan mengelola rumah tangganya sendiri. (Novriaman, 2019:3) Kabupaten Dharmasraya adalah salah satu Kabupaten di Sumatera Barat, Indonesia dengan luas wilayah 302.599 Ha dan jumlah penduduk 207.894 jiwa dengan administrasi pemerintahan yang meliputi 11 (sebelas) Kecamatan. Mengingat sektor persampahan di Kabupaten Dharmasraya masih banyak terdapat kendala maka dalam rangka menjalankan hak Otonomi Daerah pemerintah Daerah Kabupaten Dharmasraya membentuk Peraturan Daerah Nomor 9 Tahun 2015 Tentang Pengelolaan Sampah yang mana dijelaskan didalam pasal 1 angka 18 bahwa pengelolaan sampah adalah suatu kegiatan yang sistematis, menyeluruh dan berkesinambungan yang meliputi pengurangan dan penanganan sampah. Sebagai upaya dalam penyelenggaraannya pemerintah daerah menyediakan sarana dan prasarana yang dibutuhkan oleh masyarakat sebagaimana diatur didalam pasal 9 dan sebagai upaya dalam mengatasi permasalahan pengelolaan sampah pemerintah daerah melarang setiap orang atau badan membuang sampah sembarangan hal ini diatur didalam pasal 39 yang berbunyi :

Pasal 39

(1) Setiap orang atau Badan, dalam pengelolaan sampah dilarang:

a. Memasukan sampah dari luar Daerah ke dalam wilayah Daerah;

b. Mengimpor sampah;

c. Mencampur sampah dengan limbah B3;

d. Mengelola sampah yang menyebabkan pencemaran dan/atau perusakan lingkungan;

e. Membuang sampah tidak pada tempat yang telah ditentukan dan disediakan;

f. Melakukan penanganan sampah dengan pembuangan terbuka di tempat pemrosesan akhir; dan/atau

g. Membakar sampah yang tidak sesuai dengan persyaratan teknis pengelolaan sampah (PERDA Nomor. 9 tahun 2015).

Berdasarkan Peraturan Daerah Kabupaten Dharmasraya Nomor. 9 Tahun 2015 Tentang Pengelolaan Sampah pasal 1 "kepala daerah adalah badan pengawas dalam suatu peraturan daerah dan dalam pelaksanaannya satuan kerja perangkat daerah atau disingkat dengan SKPD merupakan perangkat daerah yang ditunjuk sebagai pelaksana dari peraturan daerah". Secara umum perangkat daerah tediri dari urusan staf yang membantu menyusun kebijakan dan koordinasi, diwadahi dalam lembaga kesekertariatan, unsur pendukung tugas kepala daerah dalam menyusun dan melaksanakan kebijakan daerah yang bersifat sfesifik, diwadahi dalam lembaga teknis daerah, serta unsur pelaksanaan urusan daerah yang diwadahi dalam lembaga dinas daerah. Dan 
penunjukan perangkat daerah tersebut diatur di dalam peraturan daerah kabupaten dharmasraya nomor. 9 tahun 2015 pasal 41 yang berbunyi:

Pasal 41

(1)Pengawasan dan pembinaan umum terhadap pengelolaan sampah di Daerah dilakukan oleh Pemerintah Daerah.

(2)Pengawasan dan pembinaan teknis terhadap pelaksanaan pengelolaan sampah di Daerah dilakukan oleh SKPD terkait.

(3)Pengawasan dan pembinaan sebagaimana dimaksud pada ayat (1) dan ayat (2), diatur lebih lanjut dalam Peraturan Bupati.

Sebagaimana dikeluarkannya Peraturan Bupati Nomor 51 Tahun 2019 Tentang Kedudukan, Susunan Organisasi, Tugas, Fungsi, Uraian Tugas Jabatan Serta Tata Kerja Dinas Lingkungan Hidup Kabupaten Dharmasraya dijelaskan bahwa Lembaga Dinas Lingkungan Hidup merupakan unsur pelaksana dari Peraturan Daerah yang mempunyai kedudukan membantu pemerintah dalam bidan lingkungan hidup sebagaimana diatur pada pasal 2 yang berbunyi:

Pasal 2

(1)Dinas merupakan unsur pelaksana urusan pemerintahan bidang lingkungan hidup.

(2)Dinas sebagaimana dimaksud pada ayat (1) dipimpin oleh Kepala Dinas yang berkedudukan di bawah dan bertanggung jawab kepada Bupati melalui Sekretaris Daerah.

(3)Dinas sebagaimana dimaksud pada ayat (1) mempunyai tugas membantu Bupati melaksanakan urusan pemerintahan dan Tugas Pembantuan yang diberikan kepada daerah di bidang lingkungan hidup.

(4) Dinas dalam melaksanakan tugas sebagaimana dimaksud pada ayat (3) menyelenggarakan fungsi:

a. Perumusan kebijakan di bidang lingkungan hidup;

b. Pelaksanaan kebijakan di bidang lingkungan hidup;

c. pelaksanaan evaluasi dan pelaporan di bidang lingkungan hidup;

d. Pelaksanaan administrasi dinas; dan

e. Pelaksanaan fungsi lain yang diberikan oleh bupati terkait dengan tugas dan fungsinya (Peraturan Bupati Nomor 51).

Berdasarkan Kedudukan Dan Susunan Organisasi Dinas Lingkungan Hidup berperan dalam melaksanakan pengawasan dan pemberian izin pengendalian lingkungan bagi pelaku usaha serta mengharuskan bagi pelaku usaha untuk memiliki tempat pengelolaan sampahnya sendiri dan Dinas Lingkungan Hidup juga berperan dalam menyediakan sarana dan prasarana tempat pengelolaan sampah seperti TPS (Tempat Penampungan Sementara), TPST (Tempat Pengolaan Sampah Terpadu), dan TPA (Tempat Pemrosesan Akhir).

Persoalan terkait pengelolaan sampah melalui peraturan perundang- undangan haruslah sesuai dengan kaidah sumber hukum Siyasah Dusturiyah yakni Al-Qur'an dan 


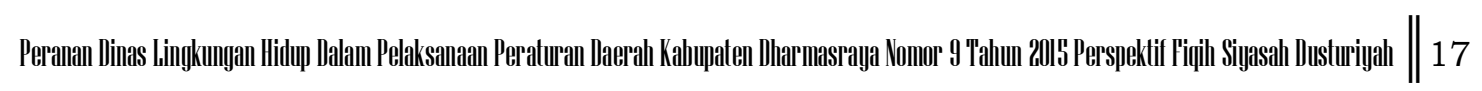

sunnah Nabi Muhammad SAW serta kebijakan ulil amri dan kebiasaan adat suatu negara yang tidak melanggar aturan syariat, Sehubungan dengan kepastian dari peranan Dinas Lingkungan Hidup dalam mengatasi permasalahan pengelolaan sampah sebagaimana diatur dalam seperangkat peraturan di Kabupaten Dharmasraya mengenai tugas dan wewenang Dinas Lingkungan Hidup dalam Hukum Tata Negara hal ini menarik untuk penulis teliti lebih lanjut dengan judul "Peranan Dinas Lingkungan Hidup Dalam Pelaksanaan Peraturan Daerah Kabupaten Dharmasraya Nomor 9 Tahun 2015 Tentang Pengelolaan Sampah Dalam Perspektif Fiqih Siyasah Dusturiyah".

\section{METODE PENELITIAN}

Jenis penelitian yang digunakan dalam penelitian ini adalah penelitian lapangan (field research) dengan mengunakan pendekatan deskriptif kualitatif. Penelitian deskriptif kualitatif adalah penelitian yang menggambarkan kejadian dan fenomena yang terjadi dilapangan sebagaimana adanya sesuani dengan kenyatan yang ada. Yang mana penelitian menguraikan kenyataan tentang "Peranan Dinas Lingkungan Hidup Dalam Pelaksanaan Peraturan Daerah Kabupaten Dharmasraya Nomor 9 Tahun 2015

Tentang Pengelolahan Sampah Dalam Perspektif Fiqih Siyasah Dusturiyah". Untuk itu pendekatan deskriptif kualitatif adalah suatu prosedur penelitian yang menghasilkan data- data yang bersifat deskritif dalam bentuk kata- kata tertulis atau lisan dari orang- orang dan prilaku yang diamati.

\section{HASIL PENELITIAN}

A. Peranan Dinas Lingkungan Hidup Kabupaten Dharmasraya Dalam Pelaksanaan Peraturan Daerah Nomor 9 Tahun 2015 Tentang Pengelolaan Sampah

Lembaga Dinas Lingkungan Hidup Merupakan lembaga pemerintahan yang mempunyai tugas membantu Bupati dalam melaksana peraturan daerah dibidang lingkungan hidup. Berdasarkan Peraturan Daerah Nomor 9 Tahun 2015 Tentang Pengelolaan Sampah Dinas Lingkungan Hidup berperan dalam mengatasi permasalahan pengelolaan sampah yang terjadi Dikabupate Dharmasraya. Berdasarkan Peraturan Bupati Dharmasraya Nomor 51 Tahun 2019 tentang Kedudukan, Susunan Organisasi, Tugas, Fungsi, Uraian Tugas Jabatan Serta Tata Kerja Dinas Lingkungan Hidup Kabupaten Dharmasraya, maka Dinas Lingkungan Hidup mempunyai peranan dalam mengatasi permasalahan pengelolaan sampah.

Berdasarkan hasil penelitian yang peneliti lakukan dikantor Dinas Lingkungan Hidup Kabupaten Dharmasraya, Dinas Lingkungan Hidup mempunyai 3 peranan penting dalam pelaksanaan Peraturan Daerah Nomor 9 Tahun 2015 Tentang Pengelolaan Sampah yaitu:

1. Dinas Lingkungan Hidup mempunyai peranan dalam mencegah terjadinya pencemaran lingkunga dengan melakukan pengawasan izin untuk mengendalikan lingkungan serta pelaksanaan penegakan hukum.

2. Dinas Lingkungan Hidup mempunyai peranan dalam penyediaan sarana dan prasarana penanganan sampah serta penetapan lokasi tempat TPS, TPA sampah. 
3. Dinas Lingkungan Hidup berperan dalam penyusunan perencanaan program dan kegiatan pembinaan, serta penyuluhan lingkungan hidup.

Sesuai dengan 3 peranan penting dari Dinas Lingkungan Hidup Kabupaten Dharmasraya adapun cara dalam pelaksanaan ke-3 peranan tersebut ialah sebagai berikut :

1) Dinas Lingkungan Hidup mempunyai peranan dalam mencegah terjadinya pencemaran lingkunga dengan melakukan pengawasan izin untuk mengendalikan lingkungan serta pelaksanaan penegakan hukum.

Berdasarkan hasil wawancara yang peneliti lakukan di kantor Dinas Lingkungan Hidup Kabupaten Dharmasraya dengan Bapak Mulyadi selaku Kasi Bidang Pentaatan Dan Penataan Lingkungan Hidup yang bertugas dalam melakukan pengawasan izin mengendalikan lingkungan dan pelaksana penegakan hukum lingkungan hidup mengatakan bahwa Dinas Lingkungan Hidup dalam mencegah pencemaran lingkungan mewajibkan kepada pelaku usaha seperti rumah makan, mini market dan kegiatan usaha lainnya untuk mempunyai tempat pengelolaan sampahnya sendiri dan dalam pembangunan TPA sampah (tempat pembuangan akhir) haruslah memiliki izin mengendalikan lingkungan dari Dinas Lingkungan Hidup.

Adapun Cara untuk memperoleh izin mengendalikan lingkungan dari Dinas Lingkungan Hidup adalah dengan melengkapi syarat- syarat sebagai berikut:

(1) Surat persetujuan prinsip/ pendaftaran usaha pada dinas penanaman modal dan pelayanan terpadu satu pintu

(2) Surat rekomendasi kesesuaian ruangan dari TKPRD (Tim Koordinasi Penataan Ruang Daerah)

(3) Surat permohonan rekomendasi dan izin lingkungan

(4) Formulir/dokumen UKL-UPL

Apabila persyaratan tersebut sudah dilengkap oleh yang bersangkutan maka Dinas Lingkungan Hidup akan memperoses data- data tersebut. Lama pemerosesan data tersebut adalah 30 hari masa kerja terhitung dari saat data-data tersebut dimasukan setelah itu Dinas Lingkungan Hidup akan memberikan surat izin mengendalikan lingkungan untuk yang bersangkutan. Dan apabila ditemukan pelaku usaha ataupun TPA yang tidak memiliki izin mengendalikan lingkungan maka Dinas Lingkungan Hidup akan memberikan sangksi kepada pelaku berupa pemberian surat peringatan ataupun teguran kepada pelaku bahkan menutup kegiatan tersebut.

Mengenai permasalahan penegakan hukum tentang pemberian sanksi kepada masyarakat yang membuang sampah sembarangan bapak mulyadi mengatakan bahwa pada saat ini Dinas Lingkungan Hidup belum ada memberikan sanksi bagi masyarakat Hal ini diakibatkan karna tidak adanya aturan yang dibuat oleh Dinas Lingkungan Hidup mengenai sanksi bagi masyarakat yang melakukan pelanggaran. Alasan dari belum adanya aturan pemberian sanksi bagi masyarakat berdasarkan keterangan dari bapak mulyadi mengatakan bahwa pada saat ini Dinas Lingkungan Hidup Kabupaten Dharmasraya belum ada membentuk tim pengawas yang ditugaskan untuk memantau keadaan dilapangan mengenai pelangaran- pelangaran yang dilakukan oleh masyarakat disebapkan karna kurangnya tenaga kerja di Dinas Lingkungan Hidup Kabupaten Dharmasraya sehingga mengakibatkan Dinas Lingkungan Hidup belum 
bisa melakukan pengawasan kepada masyarakat dan karna itulah Dinas Lingkungan Hidup belum bisa untuk membuat aturan mengenai pemberian sanksi bagi masyarakat (wawancara dengan Bapak Mulyadi Kasi Bidang Pentaatan Dan Penataan Lingkungan Hidup pada tanggal 31 maret 2020, jam 09.37 WIB).

Seperti yang telah diuraikan diatas bahwa Dinas Lingkungan Hidup memiliki peran strategis dalam mencegah perusakan atau pencemaran lingkungan dengan melakukan pengawasan izin mengendalikan lingkungan bagi pelaku usaha dan pembangunan TPA sampah. Namun dalam kenyataannya yang peneliti temukan dilapangan masih banyak pelaku usha dan pembangunan TPA sampah yang tidak memiliki izin dari Dinas Lingkungan Hidup. Seperti TPA sampah dikecamatan Sungai Rumbai yang tidak mempunyai izin mengendalikan lingkungan dari Dinas Lingkungan Hidup.

Berdasarkan wawancara yang peneliti lakukan dengan Bapak Taswirmansyah selaku ketua kebersihan yang membangun TPA tersebut mengatakan bahwa TPA tersebut dipergunakan untuk membuang sampah yang berasal dari pasar, toko, dan jalan- jalan dikecamatan sungai rumbai. Mengenai tidak adanya izin dalam pembangunan TPA tersebut bapak taswirmansyah mengaku tidak tau jika harus mempunyai izin dalam pembangunan TPA tersebut selama ini dirinya hanya meminta izin kepada Wali Nagari Sungai Rumbai saja untuk membangun TPA tersebut menurut pengakuan Bapak Taswirmansyah TPA sekarang yang terletak di belakang SMA N. 1 Sungai Rumbai tersebut merupakan TPA kedua yang ia bangun karna TPA yang pertama yang terletak di dekat Pasar Sungai Rumbai sudah penuh dan sudah ditimbun dari semenjak TPA pertama dibangun sampai TPA yang sekrang Bapak Taswirmansyah mengaku belum pernah mendapatkan teguran dari Dinas Lingkungan Hiddup sendiri (Wawancara dengan Bapak Taswirmansyah ketua kebersihan Kecamatan Sungai Rumbai pada tanggal 13 Maret 2020, jam 14.18 WIB).

Mengenai permasalahan TPA di Kecamatan Sungai Rumbai yang tidak memiliki izin mengendalikan lingkungan serta tidak memenuhi persayaratan dalam pembangunan TPA disini peneliti menanyakan hal tersebut kepada Dinas Lingkungan Hidup mengapa pelaku pembangunan TPA tersebut tidak ada diberikan sanksi padahal Dinas Lingkungan Hidup berperan dalam melakukan pengawasan lingkungan dengan mewajibkan kepada pelaku kegiatan pengelolaan sampah untuk memiliki izin mengendalikan lingkungan dari Dinas Lingkungan Hidup dan apabila ditemukan pelaku kegiatan yang tidak memiliki izin maka Dinas Lingkungan Hidup akan memberikan sanksi berupa surat teguran dan pemberhentian kegiatan pengelolaan sampah tersebut. Namun dalam kenyataannya Dinas Lingkungan Hidup membiarkan hal tersebut TPA sampah yang ada di Kecamatan Sungai Rumbai masih bisa berjalan sampai sekrang meski tidak ada izin dari Dinas Lingkungan Hidup dan Dinas Lingkungan Hidup pun tidak ada memberikan peringatan atau teguran kepada pelaku.

Berdasarkan hal tersebut peneliti menanyakan kepada Dinas Lingkungan Hidup mengapa tidak adanya sangsi tegas yang diberikan kepada pelaku kegiatan pembangunan TPA sampah di Kecamatan Sungai Rumbai berdasarkan hasil wawancara yang penulis lakukan dengan Bapak Mulyadi selaku seksi Bidang Penataan Dan 
Pentaatan Lingkungan Hidup beralasan bahwa sebenarnya Dinas Lingkungan Hidup sudah mengetahui bahwa TPA sampah yang ada di Kecamatan Sungai Rumbai tersebut merupakan TPA sampah yang illegal dan tidak sesuai dengan prosedur yang di tetapkan oleh Dinas Lingkungan Hidup Kabupaten Dharmasraya pertama, lokasi TPA sampah di Sungai Rumbai sendiri dekat dengan permukiman warga dan juga dalam pengelolaan sampahnya dilakukan dengan cara dibakar sebenarnya dalam pengelolaan TPA tidak diperbolehkan melakukan pembakaran terbuka namun dalam kenyataannya TPA di Sungai Rumbai sampah tersebut dibkar. Alasan dari kami membiarkan TPA tersebut tetap berjalan karna mengigat TPA yang kami sediakan baru ada satu yang berlokasi di Setiung V Robusa sudah tidak dapat lagi menampung sampah- sampah dari setiap kecamatan karna TPA sampah yang kami sediakan sudah melebih kapasitas daya tampungnya hal ini karna sampah- sampah dari 11 kecamatan di Dharmasraya semuanya dibuang ke TPA tersebut karna itu lah mengapa Dinas Lingkungan Hidup membiarkan TPA di Kecamatan Sungai Rumbai tetap berjalan dan tidak ada teguran yang diberikan karna TPA sampah yang ada di Kecamatan Setiung V Robusa sudah tidak dapat lagi digunakan secara optimal. Dan juga pada saat ini Dinas Lingkungan Hidup akan membuat TPA baru tapi masih terkendala dengan sertifikat tanah yang dimiliki belum dikeluarkan oleh pemerintah daerah oleh sebap itu pada saat ini Dinas Lingkungan Hidup belum bisa menyediakan TPA sampah yang baru.

Dengan demikian dapat peneliti simpulkan bahwa Dinas Lingkungan Hidup belum optimal dalam melakukan pengawasan lingkungan hal tersebut dapat dilihat dari pembangunan TPA yang ada di Kecamatan Sungai Rumbai yang tidak memiliki izin pembangunan tetapi masih dapat berjalan sampai sekarang dari sini peneliti simpulkan peranan dinas lingkungan hidup dalam penegakan hukum bagi pelaku pelanggaran pengelolaan lingkungan masih kurang optimal dilakukan oleh Lembaga Dinas Lingkungan Hidup.

2. Dinas Lingkungan Hidup mempunyai peranan dalam penyediaan sarana dan prasarana penanganan sampah serta penetapan lokasi tempat TPS, TPA sampah.

Berdasarkan hasil wawancara yang penulis lakukan dengan Ibu Jumalita selaku Kasi Pengelolaan Sampah Dan Limbah B3 menyatakan bahwa dalam pelaksanaan penyediaan sarana dan prasarana pengelolaan sampah berupa TPS (Tempat Pembuangan Sementara) seperti tempat sampah terpilah dan gantungan sampah pada saat ini Dinas Linkungan Hidup sudah menyediakan beberapa fasilitas tempat pengelelolaan sampah yang disediakan dibeberapa perumahan warga pada saat ini. Dinas lingkungan hidup juga mengatakan bahwa pada saat ini sudah ada tambahan 12 tempat sampah terpilih untuk beberapa perumahan nantinya. Disini Dinas Lingkungan Hidup juga berkerja sama dengan Tim Kebersihan di setiap kecamatan untuk mengangkut sampahsampah tersebut dari perumahan warga. Pelaksanaan pengangkutan sampah biasanya dilakukan 2 kali dalam seminggu dan akan dipungut biaya pengangkutan Rp. 12.000,00 (dua belas ribu rupiah) perminggunya oleh Tim Kebersihan disini juga kami memberikan bantuan berupa transportasi kendaraan truk pengangkut sampah dan becak sampah untuk Tim Kebersihan disetiap kecamatan. Dan juga Dinas Lingkungan Hidup menyediakan bak penampung sampah sebanyak 14 unit yang akan diletakan disetiap pasar yang ada dikecamatan, salah satu bak penampung sampah yang diletakan berada 
di daerah pasar Blok B 2 unit bak penampung sampah dan 1 unit dipasar ampalu serta 1 unit lagi didekat pasar harian dekat irigasi (wawancara dengan Ibu Jumalita selaku Kasi Pengelolaan Sampah Dan Limbah B3 pada tanggal 30 Maret 2020, jam 10.00 WIB).

Sementara itu dalam pelaksanaan penyediaan TPA sampah berdasarkan hasil wawancara dengan Bapak Mulyadi mengatakan bahwa pelaksanaan pembangunan TPA sampah haruslah terlebih dahulu menyediakan tanah untuk pembangunan TPA sampah dalam penyediaan tanah untuk pembangunan TPA haruslah tanah dari Pemerintah Daerah yang bersertifikat dan apabila tidak bersertifikat maka dana dari DAK ( dana alokasi khusus) tersebut tidak bisa diturunkan kebawah sehinga pembangunan TPA tidak dapat dilaksanakan tapi jika tanah tersebut bersertifikat maka dana DAK dapat diturunkan dan pembangunan TPA dapat dilaksanakan. Pada saat ini TPA yang ada di Kabupaten Dharmasraya terletak di Kecamatan Setiung V Robusa dengan luas 4,700 Ha dalam seharinya TPA tersebut menampung sebanyak 10 sampai 12 ton sampah perhari dari semua kecamatan yang ada di Kabupaten Dharmasraya (wawancara dengan Bapak Mulyadi Kasi Bidang Pentaatan Dan Penataan Lingkungan Hidup pada tanggal 31 maret 2020, jam 09.37 WIB).

Seperti yang telah diuraikan diatas bahwa Dinas Lingkungan Hidup memiliki mempunyai peranan dalam penyedian dan penetapan lokasi saran dan prasarana di setiap kecamatan. Namun dalam kenyataannya yang peneliti temukan dilapangan di daerah kecamatan sungai rumbai belum ada tersedia tempat gantungan sampah ataupun tempat sampah terpilah sehingga mengakibatkan banyaknya terjadi penumpukan sampah ditepi- tepi jalan dan lahan kosong di Kecamatan Sungai Rumbai. Berdasarkan hasil wawancara yang peneliti lakukan dengan Ibu Gusniarti selaku masyarakat mengatakan bahwa diperumahan tempat Ibu Gusniarti tinggal sekarang tepatnya di Jorong Sungai Kepuning tidak ada tempat sampah yang disediakan bagi masyarakat disekitar berdasarkan keterangan yang peneliti dapatkan dari Ibu Gusniarti mengatakan karna tidak adanya tempat sampah yang tersedia disekitar perumahan warga membuat Ibu Gusniarti membuang sampah hasil dari sisa kegitan rumah tangganya ketepi jalan hal itu dilakukan karna tidak adanya tempat sampah yang ada disediakan dari pada ditumpukan dirumah malah menimbulkan bau busuk nantinya jika dibiarkan berhari- hari (Wawancara dengan Ibu Gusniarti pada tanggal 11 Maret 2020, jam 15.00 WIB).

Tidak hanya Ibu Gusniarti saja yang melakukan pembuangan sampah sembarangan ketepi jalan berdasarkan wawancara pada hari yang sama yang peneliti lakukan dengan Ibu Lastri selaku masyarakat yang berada di Jorong Tanah Merah mengatakan bahwa dirinya juga melakukan pembuangan sampah ketepi jalan hal itu dilakukan karna tidak adanya tempat sampah yang tersedia berdasarkan hasil keterangan yang peneliti dapatkan dari lbu Lastri mengatakan membuang sampah kejalan itu memang salah dan juga sudah dilarang tapi harus bagaimana lagi jika tempat sampah ada disediakan ibu juga tidak akan membuang sampah ke tepi jalan (Wawancara dengan Ibu Lastri pada tanggal 11 Maret 2020, jam 16.00 WIB). 
Berdasarkan hasil wawancara yang peneliti lakukan dapat disimpulkan bahwa peranan dari Dinas Lingkungan Hidup masih belum optimal dalam penyediaan sarana tempat sampah bagi masyarakat disetiap kecamatan. Hal tersebut dapat dilihat dari masih adanya perumahan dikecamatan sungai rumbai yang tidak memiliki tempat sampah sehingga membuat masyarakat banyak melakukan pelanggaran dengan membuang sampah ketepi jalan meskipun masyarakat tau hal tersebut tidak diperbolehkan tapi masyarakat tetap melakukannya dengan alasan tidak adanya tempat pembuangan sampah yang ada disediakan.

\section{Dinas Lingkungan Hidup berperan dalam penyusunan perencanaan program dan kegiatan pembinaan, serta penyuluhan Lingkungan Hidup.}

Berdasarkan hasil wawancara yang peneliti lakukan dengan Bapak Mulyadi Selaku Kepala Seksi Bidang Penataan Dan Pentaatan Lingkungan Hidup tentang bagaimana pelaksanaan kegiatan pembinaan serta penyuluhan lingkungan hidup mengatakan bahwa dalam pelaksanaan pemeliharaan lingkungan hidup Dinas Lingkungan Hidup Kabupaten Dharmasraya membuat beberapa program kegiatan kerja yang mana pada saat ini Dinas Lingkungan Hidup sudah menyusun beberapa program kegiatan yang pertama adalah program pengelolaan ruang terbuka hijau yang mana dalam pelaksanaan kegiatan ini dilakukan dengan mengutus 5 orang anggota taman (pasukan hijau) untuk melakukan perawatan dan pembersihan ruang terbuka hijau. Pada saat ini program tersebut sudah berjalan cukup baik, anggota taman yang sudah diutus sudah melakukan pembersihan terhadap beberapa taman yang ada di Pulau Punjung dan melakukan pengawasan agar tidak terjadi kerusakan. Yang kedua adalah program pengendalian pencemaran dan perusakan lingkungan dengan melakukan kegiatan gerakan sumbar disini Dinas Lingkungan Hidup akan mengadakan lomba bersih dan hijau dikecamatan dan kelurahan dengan melakukan penilaian kepada 26 kecamatan dan kelurahan dan bagi kecamatan atau kelurahan yang menang kami akan memberikan penghargaan berupa piagam yang langsug diberikan oleh Bupati bagi kecamatan dan kelurahan yang mendapatkan nilai terbaik adapun agaran dalam pelaksanaan kegiatan ini ialah Rp. 67.078.000 juta. Dan yang ketiga Dinas Lingkungan Hidup juga melakukan program kerja peningkatan operasi dan pemeliharaan sarana dan prasarana persampahan pelaksanaan kegiatan tersebut dilakukan dengan cara melakukan pengecekan terhadap sarana dan prasarana pengelolaan sampah apabila terdapat sarana ataupun sarana yang rusak Dinas Lingkungan Hidup akan melakukan perbaikan terhadap sarana yang rusak adapun anggaran dana yang digunakan dalam kegiatan ini ialah Rp. 301.548.250 juta.

Adapun pelaksanaan pembinaan yang Dinas Lingkungan Hidup lakukan ialah mengadakan penyuluhan atau sosialisasi kepada badan usaha atau pun kegiatan pengelolaan lingkungan. Badan usaha dan pengelolaan lingkungan yang kami lakukan penyuluhan pada saat ini kami lakukan hanya bagi pelaku kegiatan pengelolaan lingkungan yang memiliki izin mengendalikan lingkungan dari Dinas Lingkungan Hidup pembinaan dilakukan dengan cara memberikan arahan tentang tata cara pelaksanaan pengelolaan lingkungan yang baik dan aman bagi lingkungan. Berdasarkan keterangan dari bapak mulyadi mengatakan pihaknya hanya dapat memberikan penyuluhan kepada kegiatan yang memiliki izin 
mengendalikan lingkungan sedangkan bagi kegiatan yang tidak memiliki izin Dinas Lingkungan Hidup tidak bisa melakukan pembinaan dengan melakukan penyuluhan karna itu tidak termasuk kedalam wewenang dari Dinas Lingkungan Hidup, wewenang Dinas Lingkungan Hidup hanyalah melakukan pembinaan kepada kegiatan yang memiliki izin mengendalikan lingkungan saja. Disini peneliti juga menanyakan apakah Dinas Lingkungan Hidup melakukan penyuluhan kepada masyarakat berdasarkan wawancara dengan Bapak Mulyadi mengatakan bahwa "dari pihak kami sendiri belum ada melakukan penyuluhan kepada masyarakat saat ini kami berfokus kepada badan usaha dan kegiatan pengelolaan sampah tapi mungkin kami akan mencoba untuk melakukan penyuluhan kepada masyarakat" (wawancara dengan Bapak Mulyadi Kasi Bidang Pentaatan Dan Penataan Lingkungan Hidup pada tanggal 31 maret 2020, jam 09.37 WIB).

Dengan demikian dapat peneliti simpulkan bahwa Dinas Lingkungan Hidup belum optimal dalam pelaksanaan peranannya hal ini dapat dilihat dari tidak adanya sosialisasi ataupu penyuluhan yang dilakukan oleh Dinas Lingkungan Hidup kepada masyarakat padahal dengan adanya sosialisasi ini, dapat menambah pemahaman dan partisipasi masyarakat dalam pengelolaan sampah namun Dinas Lingkungan Hidup tidak ada melakukan penyuluhan kepada masyarakat hal ini sangatlah disayangkan mengigat masyarakat sebagai pelaku yang banyak melakukan pelanggaran dalam lingkungan hidup sehingga perlunya dilakukan pembinaan.

B. Kendala Peranan Dinas Lingkungan Hidup Kabupaten Dharmasraya Dalam Menjalankan Peraturan Daerah Nomor 9 Tahun 2015 Tentang Pengelolahan Sampah

1. Tidak adanya Tim Pengawas lapangan yang diturunkan

Berdasarkan hasil wawancara yang peneliti dapatkan dari Bapak Mulyadi Selaku Seksi Bidang Penataan Dan Pentaatan Lingkungan Hidup mengatakan alasan dari belum adanya Tim Pengawas lapangan yang dibentuk oleh Dinas Lingkungan Hidup disebapkan oleh kurangnya tenaga kerja yang ada di Dinas Lingkungan Hidup sehingga mengakibapkan tidak dapatnya Dinas Lingkungan Hidup membentuk Tim Pengawas lingkungan. Berdasarkan hasil dari wawancara dengan Bapak Mulyadi mengatakan bahwa pada saat ini Dinas Lingkungan Hidup hanya mempunyai 15 orang tenaga kerja.

2. Mahalnya sarana dan prasarana pengelolaan sampah

Berdasarkan hasil wawancara yang peneliti lakukan dengan Bapak Mulyadi mengatakan bahwa alasan kurangnya sarana dan prasarana yang disediakan oleh Dinas Lingkungan Hidup diakibatkan karna mahalnya harga dari sarana dan prasarana pengelolaan sampah tersebut. Berdasarkan keterangan dari Bapak Mulyadi harga dari satu set konteiner bak sampah sendiri berkisaran 20 juta rupiah dan tempat sampah terpilah satu setnya seharga 5 juta rupiah sedangkan dana yang keluar untuk peningkatan operasi penyedian sarana dan prasarana yang disediakan oleh Pemerintah Daerah hanya sebesar 301.548 .350 juta dana tersebut tidak hanya digunakan untuk penyedian TPS sampah saja tetapi juga untuk melakukan pemeliharaan sampah dari sumbernya dan untuk membayar retribusi sampah sehingga 
mengakibatkan Dinas Lingkungan Hidup belum dapat secara optimal untuk menyediakan sarana dan prasarana tempat pengelolaan sampah bagi setiap kecamatan masyarakat (wawancara dengan Bapak Mulyadi Kasi Bidang Pentaatan Dan Penataan Lingkungan Hidup pada tanggal 31 maret 2020, jam 09.37 WIB).

3. Susahnya menetukan lahan untuk pembangunan TPA

Berdasarkan hasil penelitian yang peneliti dapatkan dari kantor Dinas Lingkungan Hidup Kabupaten Dharmasraya bahwa kendala dari pembangunan TPA sampah pada saat ini terkendala pada lahan atau tanah untuk pembangunan TPA sampah. pada saat ini TPA yang ada kabupaten Dharmasraya hanya tterdapat 1 TPA sampah dan TPA tersebut sekrang sudah tidak mampu lagi untuk menampung jumlah sampah yang masuk oleh karna itu Dinas Lingkungan Hidup sudah berencana akan membangun TPA baru namun pada saat ini hal tersebut terkendala oleh penyedian lahan yang ada.

Berdasarkan hasil wawancara dengan Bapak Mulyadi yang peneliti lakukan bahwasannya dalam penyedian lahan untuk pembangunan TPA sampah harus lah tanah milik Pemerintah Daerah dan bersertifikat apabila lahan tersebut tidak memiliki sertifikat dari Pemerintah Daerah dana untuk pembangunan TPA tidak dapat dicairkan oleh Ditjen Cipta Karya dari Provinsi Sumtra Barat oleh karna itu lahan untuk pembangunan TPA harus lah memiliki sertifikat dari pemerintah daerah agar dana dari atas bisa dicairkan kebawah berdasarkan keterangan dari Bapak Mulyadi saat pembanguanan TPA sampah di Setiung V Robusa kami mendapatkan dana sebear sebesar 4 miliyar untuk pembangunan TPA tersebut. Dan jika untuk sekarang kami tidak tau berapa dana untuk pebangunan TPA sampah yang diberikan masyarakat (wawancara dengan Bapak Mulyadi Kasi Bidang Pentaatan Dan Penataan Lingkungan Hidup pada tanggal 31 maret 2020, jam 09.37 WIB).

4. Tidak adanya Penegakan Hukum kepada masyarakat

Berdasarkan hasil wawancara yang peneliti lakukan di kantor Dinas Lingkungan Hidup Kabupaten Dharmasraya bersama Bapak Mulyadi alasan dari tidak adanya aturan mengenai penegakan hukum kepada masyarakat disebapkan bahwa kami belum mampu untuk membuat peraturan mengenai pemberian sanksi kepada masyarakat dan apabila Dinas Lingkungan Hidup membuat aturan tersebut haruslah dengan mendapatkan izin dari Bupati Dharmasraya dan dalam pembuatan aturan ini kami harus mempertimbangan banyak hal untuk penetapan peraturan tersebut agar tidak ada pihak yang merasa dirugikan dalam penetapan sebuah aturan dan juga sebenernya kami sudah punya rencana untuk mencoba membuat aturan tersebut pada tahun 2020 ini namun itu masih rencana Dinas Lingkungan Hidup saja belum tau pastinya kapan akan kami laksanakan masyarakat (wawancara dengan Bapak Mulyadi Kasi Bidang Pentaatan Dan Penataan Lingkungan Hidup pada tanggal 31 maret 2020, jam 09.37 WIB).

Berdasarkan uraian diatas mengenai kendala dari Dinas Lingkungan Hidup dalam melaksanakan perananya dapat peneliti simpulkan bahwa kurangnya tenaga kerja yang dibutuhkan oleh Dinas Lingkungan Hidup merupakan penyebap dari tidak adanya tim pengawas lapangan yang dibentuk oleh Dinas Lingkungan Hidup dan mahalnya biaya dalam pembeliaan sarana dan prasarana pengelolaan sampah juga menjadi kendala bagi dinas lingkungan hidup untuk dapat menyediakan sarana dan prasarana bagi setiap kecaatan serta susahnya mencari lahan untuk TPA dan tidak adanya aturan 


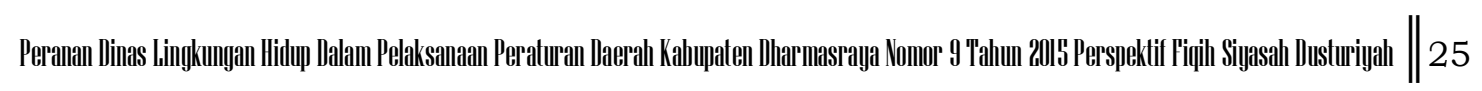

yang mengatur tentang pemberian sanksi bagi masyarakat yang melanggar menjadi kendala bagi Dinas Lingkungan Hidup dalam Pelaksanaan Peraturan Daerah Nomor 9 Tahun 2015 Tentang Pengelolaan Sampah.

\section{Penerapan Peraturan Daerah Nomor 9 Tahun 2015 Tentang Pengelolaan Sampah Menurut Perspektif Fiqih Siyasah Dusturiyah}

Dalam kaidah ushul figh adanya Peraturan Daerah tentang pengelolaan sampah ini termasuk dalam fath adz-dzari'ah yang secara terminologi bisa dipahami bahwa fath adz$d z a r i$ 'ah adalah menetapkan hukum atas suatu perbuatan tertentu yang pada dasarnya diperbolehkan, baik dalam bentuk membolehkan (ibahah), menganjurkan (istihab), maupun mewajibkan (ijab) karena perbuatan tersebut bisa menjadi sarana terjadinya perbuatan lain yang memang telah dianjurkan atau diperintahkan. Salah satu contoh dari fath adz-dzari'ah yaitu jika menuntut ilmu adalah sesuatu yang diwajibkan, maka wajib pula segala hal yang menjadi sarana untuk tercapai usaha menuntut ilmu, seperti membangun sekolah dan menyusun anggaran pendidikan yang memadai. Begitu pula dengan dibentuknya Peraturan Daerah Kabupaten Dharmasraya Nomor 9 Tahun 2015 Tentang Pengelolaan Sampah tersebut menjadi salah satu upaya yang dilakukan Pemerintah Daerah untuk membuat masyarakat menjadi lebih tertib menjaga kebersihan dan membuat masyarakat menjadi lebih mengerti bagaimana cara mengelola sampah dengan baik dan benar sehingga tidak menimbulkan kemudharatan dari perbuatan yang dilakukan oleh manusia itu sendiri. Contohnya seperti membuang sampah sembarangan yang akan menimbulkan banjir, penyakit dan sebagainya.

Allah SWT melarang perbuatan yang menimbulkan kerusakan di muka bumi dan hal-hal yang membahayakan kelestarian. Yakni dengan perasaan takut tehadap siksaan yang ada di sisi-Nya. Sesungguhnya rahmat Allah selalu mengincar orang-orang yang berbuat kebaikan, yaitu orang-orang yang mengikuti perintah-perintah-Nya dan menjauhi larangan-larangan-Nya. Dari uraian diatas mengenai Perspektif Fiqih Siyasah Dusturiyah Terhadap Pengaturan Peraturan Daerah Kabupaten Dharmasraya Nomor 9 Tahun 2015 Tentang Pengelolaan Sampah dapat peneliti simpulkan bahwa penetapan kebijakan dalam pengelolaan sampah diperbolehkan karna mengurus dan mengatur kepentingan dan kemaslahan manusia bersama-sama dalam membuat Lingkungan yang bersih dan menghindari kerusakan yang diperbuat oleh manusia. Allah SWT melarang perbuatan yang menimbulkan kerusakan di muka bumi dan halhal yang membahayakan kelestarian. Yakni dengan perasaan takut terhadap siksaan yang ada disisi-Nya. Sesungguhnya rahmat Allah selalu mengincar orang-orang yang berbuat kebaikan, yaitu orang-orang yang mengikuti perintah-perintah-Nya dan menjauhi larangan-larangan-Nya.

\section{DAFTAR PUSTAKA}

Muhammad Iqbal 2014. Fiqh Siyasah, Konstektualisasi Doktrin Politik Islam'. Jakarta: Prenadamedia Group.

R. Sutyo Bakir 2009. Kamus Lengkap Bahasa Indonesia, Tanggerang: Karisma Publishing Group 
Peraturan Bupati Dharmasraya Nomor 51 Tahun 2019 Tentang Kedudukan, Susunan Organisasi, Tugas, Fungsi, Uraian Tugas Jabatan Serta Tata Kerja Dinas Lingkungan Hidup Kabupaten Dharmasraya (PERBUP)

Peraturan Daerah Kabupaten Dharmasraya Nomor 9 tahun 2015 tentang pengelolahan sampah

Soerjono Soekanto 2002. Sosiologi Suatu Pengantar, Jakarta : Rajawali Press

Sugiyono. 2013. Metode Penelitian Kuantitatif kualitatif Dan R\&D. Bandung: Alfabeta

Situmorang J. 2012. Politik Ketatanegaraan Dalam Islam (Siyasah Dusturiyah. Bandung: Pustaka Setia

Undang-Undang Republik Indonesia Nomor 23 Tahun 2014 Tentang Pemerintah Daerah sebagaimana telah diubah beberapa kali terakhir dengan Undang-Undang Nomor 9 Tahun 2015 tentang Perubahan Kedua atas Undang-Undang Nomor 23 Tahun 2014 tentang Pemerintahan Daerah

Undang- Undang Nomor. 18 tahun 2008 pasal 1 tentang Pengelolaan Sampah dijelaskan bahwa Undang-Undang Nomor 32 Tahun 2009 Tentang Perlindungan dan Pengelolaan Lingkungan Hidup Undang-Undang Nomor 32 Tahun 2009(UUPPLH)

Undang-Undang Dasar 1945 Alenia IV

UUD RI 1945, Pasal 28 H ayat (1) 